Temasektion

\section{Keywords}

Den russiske ortodokse kirke, patriark Kirill, messianisme, fundamentalisme, eskatologi
1 Literature on the return of the ROC to the center of social and political life in post-Soviet Russia is vast. See among others: Bremer 2013; Daniel 2006; Richters 2012; Knox 2004.

2 All webpages in this article were accessed on 16 March 2021.

\title{
The Russian Orthodox Church and the Pandemic: Problems, Challenges, Responses
}

\begin{abstract}
The article discusses the reaction of the Russian Orthodox Church on the pandemic of COVID-19. This research identifies and analyzes major ideological cleavages on this issue, such as the possibility of transmitting viruses via the Eucharist, the religious meaning of the pandemic, and possibilities of digitalizing the rituals. The article pays special attention to the camp of Orthodox fundamentalists, whose reaction to the corona-crisis partially follows the international model of "COVID-dissidence" and partially taps into the domestic Russian sources, such as the mainstream ideology of geopolitical Messianism, entertained by the authoritarian regime. The author argues that the Orthodox take on COVID-19 magnifies major problems of the post-Soviet Church, including the excessive reliance on the state, "magical-fundamentalist" inclinations of the religious believers, and fears of digitalization.
\end{abstract}

The Russian Orthodox Church (ROC), after a period of hibernation under communism, accompanied by anti-religious campaigns, prosecution of the believers, and pushing religion into the margins of society, rapidly recovered during the past three decades. ${ }^{1}$ There were less than 20 per cent of the population which identified itself with Orthodoxy in the late 1980s, whereas, since 2009, the percentage of Orthodox believers (self-identified as such) stabilised itself between 70 and 80 per cent (Velikii 2020). ${ }^{2}$

Mikhail Suslov is Assistant Professor of Russian Politics and History at the Department of Cross-Cultural Studies, University of Copenhagen. His academic interests revolve around Russian and East European ideologies, utopias and political concepts, including those, inspired by religion. Recently he has published the monograph Geopolitical Imagination: Ideology and Utopia in Post-Soviet Russia (Ibidem, 2020) and co-edited volumes Contemporary Russian Conservatism: Problems, Paradoxes and Perspectives (Brill, 2019) and The PostSoviet Politics of Utopia: Language, Fiction and Fantasy in Modern Russia (I.B. Tauris, 2019). 
The Church continued to consolidate itself institutionally since the enthronement of Kirill Gundiaev as the Patriarch of Moscow and All Russia in 2009 (the number of parishes increased from 29 thousand to 39 thousand in the period between 2009 and 2018), and more significantly - it has latched on to the idea of becoming the ultimate moral authority in society, or, as one of the Church bishops put it, 'the voice of people's consciousness' (Alfeev 2014, 85). The ROC's presence in schools, army, artistic production, and mass media is quite palpable, while its self-anointed role as the major ideology supplier underpins the 'traditional values' agenda of the Russian leadership. ${ }^{3}$ The Russian Constitution was amended on 1 July 2020, by adding a block of ideological statements. The main country's document now specifically requires the state to 'keep the memory about ancestors who passed their ideals and the belief in God to us' (Art. 67.1, para. 2), and establishes the traditional understanding of 'family' as a union of a man and a woman (Art. 72, para. 1. $\nVdash^{4}$ ). Thus, in contradistinction to Art. 14 of the same Constitution which proclaims Russia a secular state, the aforementioned amendments documented the increased role of the ROC, and the traditional morality in the current Russian political regime.

Relationships between the secular and religious authorities are not always harmonious, however, in spite of the high degree of symbiosis and ideological compliance between the Russian regime and the ROC. The socio-political doctrine of the ROC, adopted in 2000, created a time-bomb for the Church-state relations, as it declared (Art III. 5, para. 4) that, 'if the authority forces Orthodox believers to apostatize from Christ and His Church and to commit sinful and spiritually harmful actions, the Church should refuse to obey the state (Basis of the Social Concept 2000; Richters 2012, 18-35). The quarantine measures during the COVID-19 crisis became precisely such a pretext for the fundamentalist constituency of the Church to call for dis-

3 The reigning narrative about the ROC's role in Russia is that separation of the Church from the State does not mean separation of the Church from society. Metropolitan Hilarion, Patriarch's vicar, argues, 'the Church may have and must have its own position on societal issues, it plays its role in society and it has possibilities to collaborate with the state' (Alfeev $2014,23)$. On the role of the ROC as a moral and ideological trendsetter see: Agadjanian 2017; Laruelle 2020; Mitrofanova 2005; Simons\&Westerlund 2015; Stoeckl
2016; Suslov 2014. On the ROC's influence in army, schools and culture see respectively: Adamsky 2020; Shnirelman 2012; Suslov 2016.

4 "Ж” is the letter in the Russian alphabet, which indicates this sub-paragraph. 
obedience, and even, as it will be shown below, to 'anathematise' the authorities. This call was considered as the stab-in-the-back by the political and religious élite by those who used to be the pillar of the Kremlin's social basis - politicised religious fundamentalists. The pandemic, thus, not only exposed internal splits in the ROC, but also turned the tables on its leadership, challenging the concept of the cordial alliance ('symphony') between the Church and the State in Russia (Chapnin 2020a, 96). The article argues that, the ROC magnifies secular political ideas, propagated by the mainstream ideologists, and then mirrors them back into the public sphere. These are geo-political, Messianic, conspiratorial, anti-Western, and identitarian ideas. When the fundamentalist constituency of the Church reflects on these ideas, however, they can seem intimidating and repugnant to the political leadership itself, which fails to recognise its own creatures in these visions.

The ROC has, of course, also its own, Church-specific attitudes to, and accounts with, the corona-crisis. To start with, the Church was hit hard by COVID-19. The project Sobornost, run by Sergei Chapnin, calculated the number of clerics, monks, and religious activists who died as a result of contracting (confirmed) COVID-19 as of 16 December 2020. The number is 334, including 235 in the territory of Russia. ${ }^{5}$ The 'Russian' list includes seven Metropolitans (out of 70): Varnava Kedrov, Iona Karpukhin, Isidor Kirichenko, Feofan Ashurkov, Iov Tyvoniuk, Sofronii Dmitruk, and Evlogii Smirnov; two bishops: Veniamin Korolev and Serafim Glushakov; and 17 hegumens (or abbots) and archimandrites (i.e. heads of the monasteries). These figures provide dramatic statistics of the death rates from COVID-19 in the ROC, which, in order of magnitude, is more than the world death rates in connection with the pandemic (e.g. Luchenko 2020). The corona-crisis had yet another, economic, effect on the ROC. The closure of churches meant the radical reduction of parish revenues, which otherwise took donations for performing services and selling candles and other religious items to the believers.

During the pandemic, religiosity increased, especially among the people with some kind of religious training received during their childhood and youth, and among those whose fam-

5 'Proekt sobornost', available at: https://www.facebook.com/ sobornost.project/ ily members contracted the virus (Molteni 2020). According to the theory of terror management, religion helps people to make sense of the dramatic changes in their lives beyond their con- 
trol. Quarantine measures, at the same time, considerably limited freedom to practice religion, attend services, take communion, worship relics, and participate in pilgrimages and processions. The Christian Churches, in the context of this paradox, re-launched the discussions about the societal relevance of religion in the world stricken by COVID-19. The relatively insignificant part of the religious community, mostly among the fundamentalists, embraced the eschatological viewpoint, and reinvigorated the concept of 'il Dio punitore' - God who punishes us for our sins. The conservative Catholics, on the other hand, advanced an interpretation of the corona-crisis as a deed of Satan, intent on pursuing people, and driving them away from churches, and eventually from salvation (Sena da Silveira 2020).

The mainstream debates repudiate the 'punishing God' interpretation (Paura 2020). Magnus Striet, for example, professor of Catholic theology from the University of Freiburg in Germany, clearly expressed the idea of the virus being irrelevant to religion: 'The epidemic is fought by medicine, not prayers' (Striet 2020). The importance of the new social reality for Churches, however, is undeniable; many religious intellectuals cautiously probe new ways of thinking about Christianity in the context of the pandemic. They honed in on, for example, the issue of the Churches' humanitarian and charitable roles during the pandemic, on digitalisation of the church services and mission, and on the legal rights to limit religious freedom in this state of emergency (Moser 2020). Catholicism, historically and theologically prone towards a vision of the Church as a provider of sacrality, rites, and a mediator between God and humanity, found the inability to perform the usual collective services during the pandemic, actualised a new, quasi-Protestant understanding of the salvific mission of the Church as primarily a role model for humility and morally-informed behaviour (Cimbalo 2020, 19). The pandemic simultaneously prompted Western Churches to rethink spatiality of religion, and to turn decisively towards sanctification of the 'new temple of the confinement - the home' (Flores 2020, 52) - and towards inclusion of the digitalised religious practices into the everyday life of a believer.

The pandemic serves to justify radical proposals of the Church renovation on the reformist flank of Christianity. A Catholic philosopher, Tomas Halik, adopts the 'punishing God' concept on a more symbolic level. He sees the empty churches during the pandemic as the metaphor of internal emptiness of 
6 On the concept of 'cosmic wars' see: Juergensmeyer 2003. See also studies on the ROC in the context of 'cosmic wars': Adamsky 2020; Mitrofanova 2005; Zygmont\&Knorre 2019; Verkhovsky 2003.

7 'The Inglehart-Welzer World Cultural Map (2020)' and 'Live Cultural Map over Time 1981-2015', available at: https://www.worldvaluessurvey.org/WVSContents.jsp 8 Here "identitarian" implies that, political debates are steered towards discussions of Russia's cultural authenticity and geopolitical sovereignty. On Russian political imagination see, among others: Suslov 2020; Lewis 2020. the Church, which cries out for both the personal transformation and the transformation of the Church (Halik 202O). The corona-crisis also prompted reflections on whether the model of a 'priestless Church' could sustain individual religiosity, and retain religious motivation in the focus of human lives (Vogt 2020,34).

The world Orthodoxy demonstrates even greater disunity regarding the issue of the pandemic, and the influence of fundamentalists is more palpable here. A part of the explanation for this, is the emphasis on the physicality of the communion, and on the communitarian practices in Orthodox religious rites, such as kissing icons, kissing the ciborium (Host bowl) after receiving the Eucharist, the tradition of common confession, and so on. The dilemma between heightened religiosity and inability to practice religion as usual during the pandemic is being perceived especially painfully by the Orthodox Churches; additionally, the religious situation in post-communist Russia is marked out by important specificities. First, most of the Church's bishops, who came of age and received the religious education under the Soviets, tend to see the world as a hostile environment around them - the chosen few true believers. This semi-sectarian vision of a 'cosmic war', characteristic of all fundamentalist religious movements, ${ }^{6}$ distorted the ROC's perception of the quarantine measures as another attempt of the belligerent, secular state and society to suppress their religious freedom (Luxmoore 2020). Second, the post-Soviet population - broadly speaking - has the long-term tendency to embrace survival values, and to practice adaptive behaviour. ${ }^{7}$ This inclination has been reinforced by the estrangement of the people from political decision-making in the present authoritarian regime (See, among others: Dawisha 2015; Gel'man 2015; Taylor 2018). An immediate result of this is the popularity of conspiratorial thinking in society. The conspiratorial explanations of the COVID-crisis have, therefore, found a very receptive soil in Russia (See, for example: Laruelle 2012; Ortmann\&Heathershaw 2012; Shnirelman 2019). Finally, ideological debates in contemporary Russia are immersed in the identitarian discourses and geo-political style of thinking. The question 'what is Russia?' attracts considerably more attention from the experts and general public than questions about the essence of freedom, equality, justice, and so on. Debates about the religious meaning of the pandemic paradoxically coalesce with the debates on Russia's confrontation with 'the West' as a result. ${ }^{8}$ 
It is important to stress that, by way of making the last methodological caveat, the article focuses on the religious worldview, which is specific for the post-Soviet Orthodox Christianity in contemporary Russia. This means that, the article is not concerned with the complex and sometimes overlapping jurisdictions of different Orthodox Churches outside the territory of the Russian Federation. The important marker of relevance of the article's sources is their presence in the Russian-speaking, religious media. The bulk of material for this article comes from the ROC inside Russia, whereas references to the discourses, originating in the Orthodox world outside Russia, are only occasionally made, when the Russian-speaking audience engages with them.

\section{Official-conservative position}

The outbreak of the coronavirus in Italy in February 2020, meant that, the administration of the Orthodox parishes in this country issued a statement, ordering priests to rigorously follow the government's quarantine instructions, including closure of the churches (Sevriuk 2020). The liberal approach to the problem, epitomised by archimandrite Cyril Hovorun, a professor of theology at the Loyola Marymount University in California, maintains that, viruses are part of God's creation, and they are not essentially 'evil', even if they can and do kill people: the same could be said of lions and bears - dangerous for humans as they might be, they are part of God's creation, not devil's work. This means that, there is no theological obstacle to accept the Eucharist itself (i.e., wine and bread) can transmit contagious deceases, and that necessary sanitary measures are due in the churches during pandemics (Hovorun 2020a; Nedelescu 2020).

The reaction of the ROC within Russia was different, oscillating between two extremities: unconditional acceptance of the quarantine measures introduced by the secular authorities, and decisive repudiation of the idea that, the holy objects and rites can transmit a disease. Representatives of the ROC in the press conference in Moscow on 3 March 2020, unequivocally said that, the Eucharist could not transmit viruses, but it did not mean that, believers, praying in the same premises, would not spread diseases among them ("Na press-konferentsii" 2020). The highest clerics and functionaries of the ROC, Metropolitan 
Hilarion Alfeev, the vicar of the Patriarch, and Vladimir Legoida, chair of the PR department of the ROC, worked out and voiced the official position of the Church along the same theological lines: the Eucharist, which is the body and blood of Christ, cannot infect people, but physical containers of the Eucharist can. The Church leadership introduced disposable ritual objects, and instructed the priests to regularly sanitise them; at the same time, they emphatically denied the possibility of closing down churches (Alfeev 2020a; Legoida 2020b).

The situation in the Russian capital and elsewhere were heightened during the spring of 2020. The Church came up with specific sanitary instructions for the priests on 17 March. This included disinfecting the spoon for the communion, laying of the cross on the heads of the communicants instead of allowing them to kiss the cross, using hygienic, disposable gloves and glasses to wash down the Eucharist, and more ("Instruktsiia nastoiateliam..." 2020). Metropolitan Hilarion admitted that, the Church would not confront the secular authorities, if they decided to close churches as part of the extraordinary, anti-epidemic measures (Alfeev 2020b); meanwhile, on 18 March, Russia banned foreigners from entering the country and flights and train connections with other countries were gradually being cancelled. The quarantine (the word 'quarantine' was not used - it was called 'self-isolation') was introduced in Russia on 25 March 2020, a decision taken by its President Vladimir Putin for the period 30 March - 3 April, which was later on extended to 30 April. To make matters worse, Easter in 2020 was on 19 April, during the quarantine, which created a painful dilemma for many practising Orthodox people; not attending the main religious celebration was utterly abhorrent.

The official position of the Church on the matter of closing churches was considered by some religious analysts as indecisive and self-damaging, driving the leadership into deadlock. Alignment with the state position led to alienation of masses of believers, while assuming the position of intransigence meant open disobedience of the state. Patriarch Kirill Gundiaev, head of the ROC, reacted to these measures by urging the clerics and lay people to follow the example of Maria of Egypt, and refrain from attending churches (Gundiaev 2020). Many believers, however, understood this address as a recommendation, and ignored it. Referring to the words of the Patriarch, one of the priests responded to the question of a parishioner about the pos- 
sibility of attending services: 'You can follow his call [and stay home].' ${ }^{9}$ It is difficult not to hear a note of disapproval in this recommendation. Critics of the Patriarch's address argue that, he could have said with greater finality that he 'blessed' (i.e., ordered) them not to go to the church (Fedosov 2020; Soldatov 2020). Dodging responsibility, the Church authorities delegated the decision on closing churches during Easter to the lower level. The common trope of the leaders of the Russian Orthodoxy had always been to 'go out of the church fence' and make the Church's voice loud in societal debates (for example Rediger 2007). When the crucial time came, however, it turned out that, the ROC's voice was faltering; as a result, many religious centres whose leaders and monks were sceptical about the quarantine, turned into infection hotspots, which ultimately decimated the inhabitants. This happened, among others, in the Trinity Lavra of St Sergius and the Kiev Pechersk Lavra - the most venerated monasteries in the ROC.

The second front on which the official-conservative line fights against the 'reformist opposition' in the ROC, is the interpretation of the religious meaning of the pandemic. Reformists say that, the pandemic is God's punishment for the priests' and bishops' sumptuous lifestyle, emphasis on the ritualistic forms of practising the religion, strengthening ties with the Russian political regime, and other vices (e.g. Badmaev 2020; Velikanov 2020). The COVID-crisis, according to this understanding, should trigger major internal rejuvenation of the Church. To undermine this demand for reforms, the conservative Church publicist Aleksandr Shchipkov pontificates: 'epidemics have no connection with the will of God. This is an ordeal, one of many, which we overcome in our lives' (Shchipkov 2020a). The official interpretation of the religious meaning of the corona-crisis, thus builds on the concept of 'normalisation' of the crisis as one among many other 'trials'. The whole life of a Christian, in this vision, is nothing more than a sequence of 'trials', which people should use in order to prepare for eternal life after death. Priest Igor' Sil'chenkov explains in his sermon, God is using the corona-crisis like any other calamity to check one's virtuousness. He argues, in people's daily lives, individuals rarely commit overt

9 Father Aleksandr Oblaukhov's response to the question, 31 March 2020, available at: https://vk.com/ topic-25505827_37176345? offset= $600>$ and grave sins such as murder, fornication, or theft, and they tend to lull their consciousness into the false belief that, they are righteous, but they are not. The epidemic shows that, people easily fall into 'minor' but still pernicious sins of dejection, resent- 
ment, and irritation, for instance. Thanks to this 'test', therefore, people can recognise their hidden sins, eradicate them, and thus save their souls (Sil'chenkov 2020).

Vladimir Legoida, the head of the PR department of the Moscow Patriarchate, put forward a similar argument. He simultaneously mounted criticism against the global, secular world, when he called the pandemic a necessary 'shakeup' for humanity. Humanity, he believed, had become too infatuated with consumerism, and had forgotten about really important things (Legoida 2020). This approach is also in line with the model of the post-Soviet proclivity for adaptive behaviour, discussed above (Levada 2001): a moment of hardship is part of God's plan to train people as good Christians and prepare them for heaven; the task of a believer is to endure this trial with humility. The official position, however, fails to account for the uniqueness and the massive scale of the present crisis, and the ROC's representation of it as something usual and relatively unimportant. The Church differs from the expectation of the believers who are affected by the virus and the quarantine, and crave to understand their religious meaning. Banalisation of the corona-crisis is another sign that, the ROC, contrary to its claims of setting the public agenda, avoids speaking about matters of concern for the Russians.

It should also be admitted here that, the 'normalisation' narrative serves the purpose of avoiding panic moods among the population. Indeed, the Orthodox clergy is (numerically) dominated by those who hold sober and rational views on the corona pandemic. The sample of 16 priests, who regularly responded to the believers' questions on social media, shows that, only one of them denied the possibility of contagion via the Eucharist, while the rest of them espoused a more science-informed attitude. They insisted that, religion deals with spiritual illnesses, and cannot guarantee physical health. This means that, people who believe they are so righteous that God would save them from viruses, fall into the deadly sin of pride. ${ }^{10}$ The priests (respondents) from the sample said that people should follow the calls of Patriarch Kirill and other dignitaries to observe all san-

10 E.g., Father Petr Gur'ianov's response to the question, 15 March 2020, available at: https://vk.com/ topic-25505827_31794807?offs et $=2740>$ itary measures. Priests such as Georgii Khristach, Andrei Mekriukov, and Sergei Shirapov, for instance, called conspiracy theories about COVID-19 'nonsense'.

At the same time, four out of 16 priests expressed cautious apprehension: they suggested that, this might be 'preparation' 
for the Anti-Christ. They gave some specific recommendations on how a believer would recognise the last days. Hegumen (abbot) Luka Stepanov, for example, mentioned that, the AntiChrist would come when the world was unipolar, and governed by one president. ${ }^{11}$ Father Sergii Romanov admitted that, the corona-crisis was the sign of the impending 'last days', but we were not yet 'there' because many other things should happen first. ${ }^{12}$ Archpriest Aleksandr Oblaukhov said that, vaccination 'is not yet the stamp of the Anti-Christ', because when the last days came, people would be explicitly, not metaphorically, asked if they would renounce Christ or not. ${ }^{13}$ The sample shows that, the 'grassroots clerics', unlike many lay people, did not display any tendency towards fundamentalist beliefs in the magical powers of the Eucharist, but, it is also remarkable that, many of them were, nevertheless, thinking about the corona-crisis in the context of the Apocalypse.

The third front of debates between the reformists and the conservative hardliners runs across the issue of digitalisation, spurred on by the closure of churches. Transmission of sermons and religious services online is nothing new for the Orthodoxy, but the possibility of the communion online is vigorously debated. Two Orthodox priests in the Ukraine ministered the 'online liturgy' in May 2020; participants displayed the Holy Sacrament (wine and bread) via their cameras to the priest on the video-conference program (such as Zoom), who blessed it from a distance, and thereby performed transubstantiation (Guliamov 2020). The logic behind this procedure is, digital transmission of images is merely a medium between the eyes of a priest and the Holy Sacrament - similar to how a priest wearing glasses can still administer the Eucharist, despite the fact that, he sees

11 Hegumen Luka Stepanov's response to the question, 24 April 2020, available at: https://vk.com/ topic-25505827_24476231?offset $=3120>$

12 Father Sergii Romanov's response to the question, 20 April 2020, available at: https://vk.com/ topic-25505827_37297023?offs et $=220>$

13 Father Aleksandr Oblaukhov's reponse to the question, 18 May 2020, available at: https://vk.com/ topic-25505827_37176345?offse $\mathrm{t}=600>$ bread and wine through the lenses. This practice met fierce condemnation and resistance by the majority of the ROC and the Ukrainian Orthodox Church. The ROC's leadership proposed that, believers would invite priests to their private homes in order to perform the liturgy there, instead of online. The abovementioned sample of 16 priests displayed a unanimous rejection of the possibility of the Eucharist online, and two of them categorically denied the validity of online confession. This 'digital anxiety' is hardwired into the ROC theology and religious practice (more on this: Suslov 2016). The new reality of the quarantine cannot simultaneously shake these complex beliefs and emotions. 
This section exposed three conflicting zones emerging from the corona-crisis in the Russian Orthodoxy: the possibility of contagion in the Church, the meaning of the pandemic, and digitalisation of the church services. The cleavage between reformist and conservative church thinkers was the focus here. The next section puts the spotlight on the 'game-changer' in these debates: the sudden, crystallised fundamentalist opposition to the religious mainstream.

\section{Fundamentalist position}

The 'Fundamentalism Project' carried out at the Chicago University between 1987 and 1995, viewed fundamentalism as an attempt 'to arrest the erosion of religious identity' (Almond, Appleby and Sivan 2003, 17). Fundamentalism's basic features from this viewpoint are opposition to the processes of marginalisation of religion, intertwining of the elements of modernity and traditionalism, moral manichaeism, belief in absolute truth of the sacred corpus of religious texts, millennialism and Messianism, sharp boundaries between the apostate, secular 'outside world' and 'true believers', and the tendency towards authoritarian practices in organising religious communities (Marty\&Appleby 1995, 399-424). Keeping this definition in mind, we can identify the fundamentalist interpretation of the corona-crisis as a belief that, this is the last warning and the last sign of the impending Apocalypse. The quarantine measures are a kind of God's trial, in this sense, which is the very last and decisive one; if people fail to manifest their allegiance to God, skip the Church services, and are afraid to take communion, they will forfeit their 'rights' for salvation. This understanding push-

14 Episodes, referred to here are: Aleksandr Kalinin, the head of the movement 'Orthodox State', spoke about punishing Aleksei Uchitel, film director, for irreverent portrayal of tsar Nicholas II in the film 'Matil'da' (e.g.:

Kots\&Chelyshev 2017). Dmitry Tsorionov, the head of the Orthodox movement 'God's Will', violently attacked the art exhibition of the religious sculptor Vadim Sidur (e.g. Nazarets, Pal'veleva and Vol'tskaia 2015). es fundamentalists towards disobedience of the Church authority, and conflict with secular powers. The COVID-crisis highlighted the relatively insignificant group of fundamentalist Orthodox believer. It also made it obvious that, the actual core of Orthodox fundamentalism was not a handful of politicised, marginal activists who pillaged 'blasphemous' museum exhibitions, and threatened to impale the film director who represented the last Russian tsar as a romantic hero; ${ }^{14}$ the vast majority of churchgoers believed their faith would save them from infections. This 'magical fundamentalism', as religious analyst Sergei Chapnin dubbed it, saw the Holy Sacrament as having super- 
powers of sorts, which would make true believers immune to all harm and illnesses (Chapnin 202ob; see also Hovorun 2020b).

The fundamentalist approach found its magisterial way of expression in the theological belief that, infection could not be transmitted during the liturgy. The fundamentalist streak in Orthodoxy, dissimilar to the official line of the ROC, saw no distinctions between the Eucharist per se and its containers. It argues that, everything connected to the ritual of the communion is 'holy', be it the ritual itself, ritualistic objects, or even the physical building of the church. Father Makarii Markish, the founder of the online social media for Orthodox believers 'Elitsy', responded to the question about the Eucharist and COVID-19. He said, 'the Church states that the Holy Sacrament does not transmit contagion. ${ }^{15}$ One of the parishioners expressed his thoughts on the Orthodox TV channel Spas, 'I firmly believe that the Eucharist transforms into the body and blood of Christ during the liturgy, so how can I possibly admit that Christ transmits contagion?' ${ }^{16}$

According to this logic, what is 'holy' is also 'healthy'. Bishop Amvrosii Skobiola claims, 'our Lord is our medicine and doctor' (Skobiola 2020). Indeed, there are some Orthodox priests, many of whom have access to various media channels, who are emphatic about the Church's ability to heal physical illnesses. The most common discourse around this topic is that, people never get ill after many decades of regularly taking communion together with others, and without any sanitary concerns. Father Andrei Lemeshonok, hegumen of one monastery in Belarus, repeatedly pointed at his own and his colleagues' experience of consuming the Holy Sacrament after communion, in which tuberculosis patients took part, with no obvious harm to the health of the priests (Lemeshonok 2020 and 2020b). Father Igor Latushko from Belarus confirmed this observation, adding his own: after the radioactive fallout from the Chernobyl nuclear plant, dosimeters went off in Belarus, but in churches, they showed zero radioactivity (Latushko 2020). Another assertion

15 Father Makarii Markish's post, elitsy.ru, 18 May 2020, available at: https://dialog.elitsy.ru/expert/15728/ 16 Elena Skorokhodova's remark on the TV show 'RE: Aktsiia', TV channel Spas, 25 March 2020, available at: https://www.youtube. $\mathrm{com} /$ watch? $\mathrm{v}=\mathrm{O}-\mathrm{W}_{5}$ wJ8Eny4 claims the ring of the church bells kills viruses, so, the best medicine against COVID-19 is to attend church as often as possible, and listen to the bells. This prejudice had to be 'officially' repudiated on the pages of the Church journal Foma (Bogdanova 2020).

Orthodox believers adhering to this 'magical fundamentalism' considered quarantine measures blasphemous, and sought 
17 Sociologists and political observers argue that, the so-called 'Crimean consensus' is over, when a considerable majority of the population supported the Russian leadership in exchange for the feeling of the regained pride as a 'great power'. Ratings of the Russian political leaders, Putin included, and state institutions are markedly falling; for example, trust in Putin dropped from $60 \%$ in 2017 to $25 \%$ in May 2020 ("Doverie politikam" 2020). possibilities to manifest their unshakable faith by ignoring sanitary instructions altogether in churches. According to their creed, God would not allow His faithful believers to contract a disease, therefore, if priests and lay people become sick and die, this is because either their death is part of God's designs, and unfathomable for mortal humans, or because they simply are not faithful enough. The reverse is also true: if people are afraid to kiss crosses and the Eucharist bowl, or to take the spoon with the Holy Sacrament into their mouths, they have too little faith (Skobiola 2020). Ignoring the sanitary restrictions thus becomes a matter of testing people on the firmness of their religious beliefs. Archpriest and film director Aleksandr Novopashin, while criticising Father Cyril Hovorun's theological opinion, insisted on the impossibility for the faithful flock to contract the virus, and proffered an idea that, the corona-crisis serves as the ultimate test, separating those 'who truly believe in Christ... and those who betrayed and sold out everyone because of their cowardice and meanness' (Novopashin 2020). Father Roman Matiushin expressed the position of the Orthodox 'COVID-dissidents' in the axiom:

Nobody kisses crosses!

People are avoiding holy icons as hotbeds of diseases:

Holy relics are not holy for people of little faith!

(Matiushin 2020).

When kissing relics and attending churches became a matter of testing faith, and manifesting one's readiness to suffer and die in the name (and in imitation of) Christ, the fundamentalist part of the flock immediately turned to dissidence to the state and to the Church leaders who collaborated with the state. Contrary to the established, post-Soviet tradition according to which the ardent, fundamentalist-inclined, Orthodox believers would automatically be supporters of the state in its struggle with the Westernised, liberal part of the population; the corona-crisis ushered in the new reality. Soviet-time memories about a repressive, atheistic state, imbricated with the growing dissatisfaction with the declining living standards, stalled economic growth, and the retirement-age extension reform thus became the new norm. ${ }^{17}$ Indeed, the rhetorical framing of the fundamentalist position often recycled the memories of the religious underground in the Soviet Union. COVID-deniers described themselves as 'dissidents' and 'inakomysliashchii' (non-orthodox thinking people, 
mavericks), juxtaposed to the oppressive secular majority (Druz' 2020). Fundamentalist disobedience to the state-imposed quarantine measures, in this context, exemplifies the broader atmosphere of distrust of institutions. This is especially true, when it comes to the Russian Orthodox Church Abroad, which is traditionally more fundamentalistically-oriented than the ROC, and more suspicious of the Russian secular state and the Moscow Patriarchate. Bishops of this Church even relate to the COVID-crisis as an eschatological sign and the global plot against Christianity. Amvrosii Timrot, for example, spoke against wearing masks (because this was the ancient earmark of a slave), and against regular washing of hands, because it evoked parallels with Pontius Pilate's washing his hands before sentencing Jesus Christ to death (Timrot 2020).

The fundamentalist take on the pandemic caters to the feeling of exceptionalism among the radicalised flock. Exceptionalism could be 'positive' and 'negative'. The country can entertain the vision of the self as the best possible in the world - the 'city on a hill'18 - but it can also be motivated by the opposite selfperception as the worst - the most wretched, unhappy, disorganised, and worthless country and people. This second version of exceptionalism taps into the religious concept of kenosis self-emptying and self-belittling in imitation of Christ: 'the last shall be first' (Mathew 20:16) and 'blessed are the poor' (Luke 6:20). One can observe multiple iterations of this kenotic exceptionalism in the past and present of Russian intellectual culture (e.g. Uffelmann 2010; Ely 2002). The kenotic-Messianic take on the quarantine measures becomes manifest in the words of Gennady Dorofeev, an Orthodox writer and journalist, who described his participation in the Easter service in circumvention of the official prohibition:

We are sinners $[\ldots]$. There are no righteous persons among us. The righteous ones are now welcoming the risen Christ in front of their TV sets [...]. This satanic illness has torn away masks from our souls [...]. Quiet and ridiculous persons turned out to be strong and manly. But it does not happen for the first time in the world. This is only the reminder of the Evangelical story. Apostles, Christ's most devoted disciples ran away in

18 U.S. exceptionalism provides an interesting case for comparison. See, among many other studies: Lipset 1996. panic, locked them off, closed doors and windows [...]. Only shy women were together with Christ to the end and after the end (Dorofeev 2020). 
This excerpt unequivocally suggests that, violation of the quarantine prohibition, imposed by the secular and religious authorities, is a feat of kenotic glory, when the wretched sinners suddenly turn into the last faithful Christians; another aspect of kenotic reading of the COVID-crisis consists of discussions about the balance between spiritual and corporal health, and the role of faith in everyday life. According to the 'magic fundamentalist' position, quarantine measures represent excessive taking care of a body at the expense of the soul. The 'cult of body' is vocally castigated, while the conviction that, God attends to people's bodily health, if they see to their spiritual health is propagated on the grounds that 'even the very hairs of your head are all numbered' (Matthew 10:30). ${ }^{19}$ All in all, an undisguised disobedience to the state in dealing with the COVID-19 condenses several layers of positive valorisation of such behaviour: dissidence to the Godless state, a sinner-turned-saint trope, and the role model of 'saving the soul by killing the body'.

The most vivid example of the religious fundamentalist dissidence is the much-discussed case of hegumen Sergii Romanov, the former head of a monastery in Yekaterinburg, who not only denied quarantine measures in a church, but also publicly damned those who followed sanitary restrictions (Romanov 2020). Father Sergii overtly blamed President Vladimir Putin for 'creating the fascist concentration camp of Satan' by adopting digital identification of citizens, and closing down churches ("Otets Sergii prizval" 2020). The Church court decided to expel him from a priesthood status for disobedience (24 July 2020), and later on, excommunicated him from the Church (10 September 2020); however, he continues his schismatic activities, and rallies a tangible group of supporters around him (Chapnin 2020c).

Metropolitan Longin Korchagin of Saratov on a less dramatic note, condemned the state's 'mad decision' to close churches,

19 Konstantin V.s response to the discussion thread of 16 November 2020, available at: https://ruskline. ru/news_rl/2020/11/14/o_aleksii_ denisov_koviddissidenty_silno_ zabluzhdayutsya

20 Metropolitan Longin Korchagin's post of 18 April 2020, available at: https://www.facebook.com/ permalink.php?story_fbid $=7110987$ 69625644\&id $=100021765816130>$ and declared that, by his decision, churches would not be closed in this diocese during the celebration of Easter. This would become, he stated in this Facebook account, the lesson for everyone, showing 'the actual attitude of the state to the Church and the Russian people. ${ }^{20} \mathrm{He}$ tried to cover up the harshness of his tone soon thereafter, but a reaction nevertheless followed: on 25 August 2020 he was removed from his See in Saratov, and sent to a less significant diocese as - presumably - an act of punishment for his dissidence (Faustova 2020). 
Another component of dissatisfaction with the political regime and personally with President Vladimir Putin came from the smouldering fears of digitalisation. The Russian Orthodoxy has always been susceptible to eschatological expectations, and time and again, exploded with panic around the 'stamp of Antichrist', predicted in the Book of Apocalypse. The quarantine measures in Russia included the need to obtain a digital code, which allowed people to exit their homes and move around in the cities. This code, together with the rumours about 'liquid chips', being injected into people during the vaccination campaign, aroused eschatological concerns among the believers that, the Antichrist had come, and hence, people faced the dilemma of surrendering to him and accepting his 'stamp' or remaining faithful to Christ by rejecting the quarantine measures and vaccination. Fears of the 'liquid chips' and other rumours were disseminated by the group of religious activists Sorok sorokov, archpriest Maksim Kolesnik (2020), and especially film director and propagator of conservative and religious ideas, $\mathrm{Ni}$ kita Mikhalkov. Mikhalkov's Youtube video clip with the alarming music in the background, argues that, the global government, presided over by Bill Gates and other American tycoons, intended to implant 'liquid chips' in order to reduce the Earth's population (Mikhalkov 2020). ${ }^{21}$

Following the pattern established in the previous section, this one homes in on three focal points in the debates between the fundamentalists and the rest of the Church: impregnability of the holy relics by viruses, religious meaning of disobedience to the state-induced quarantine measures, and the perniciousness of digitalisation. The next and final section pays particular attention to one aspect of the fundamentalist thinking about COVID-19, namely, the relationship of the pandemic to the global geopolitical problems.

\section{Geopolitical and conspiratorial interpretations}

21 Cf. another moral panic COVID vaccination was initiated by Cardinal Antonio Cañizares, who feared that vaccines would be produced from unborn foetuses (Lorenzo 2020).
Orthodox fundamentalists merge eschatological and conspiratorial narratives with the claim of Russia's spiritual superiority in comparison to other Christian countries; by extension of the fundamentalist logic, analysed in the previous section, the quarantine measures undertaken in Western Christian Churches, are considered as a weakness of faith. It should be noted that, the 
vision of the West as the place of apostasy and moral corruption has been persistently circulating in the religious and secular Russian media in the past two decades. Metropolitan Hilarion, for example, called liberalising tendencies in Western Christian Churches 'treason', as a result of which 'Christianity loses its internal force, and stops being attractive, so churches become empty' (Alfeev 2014, 192). Patriarch Kirill likewise maintained that, empty churches in the 'West' were the sign of forgetting about the concepts of sin and morality, and pandered to the egoistic whims of the fallen man (Gundiaev 2009a, 19). Kirill also sees infatuation with the ideals of Enlightenment in Western theology; in his view, it is the sign of surrender to the spirit of secularism (Gundiaev 2009b, 129). Patriarch Kirill insisted elsewhere that, Russia should always remember its 'spiritual primogeniture' in relation to the West, meaning Russia's superiority in religious issues (Gundiaev 2009a, 146-7).

When the religious leaders spoke about secularism, amoralism, and anti-Christian tendencies, they consistently kept in the back of their minds that, these evils originated in 'the West', and from there, they threatened to engulf Russia, implying primarily such things as women's priesthood, acceptance of samesex marriages, and tolerance towards LGBT+ people. Indeed, for Patriarch Kirill, all Western Europe is the hostile world, because, as he explicitly stated, European values as we know them today, emerged from the non-Christian grounds (Gundiaev 2010, 120). One of the Orthodox activists juxtaposed apostate Western Churches to faithful Russia in the following verses he created:

The soul is torn apart,

Will Paris, Rome, and Berlin fall?

They are sitting in the prison cells,

And believe that this is quarantine.

... I kiss the icon in the church,

I kiss the cross and worship it,

My Russia is standing in front of God,

And will always be standing until the end of time!

(Krasil'nikov 2020).

22 On Russian Messianism see, for example: Curanović 2019; Duncan 2002.
This juxtaposition to the West is aligned with the Messianic perception of Russia's uniqueness, and its global salvific role. ${ }^{22}$ Ruskline.ru - the outspokenly fundamentalist Orthodox news 
portal adopted the geopolitical-Apocalyptic interpretation of the COVID-crisis. This may vary in ideological articulation, but the bottom line is the same: the pandemic is the result of some geopolitically-external hostile, anti-Christian, and anti-Russian forces. Publicists of this news outlet argue, for example, that the pandemic is the result of the godless and Satanic tendencies in the West such as normalisation of trans-gender persons in Norway (Rybakov 2020); another publicist aligns God's pandemic ordeal with the cartoon of Prophet Mohammed in France, and offensive attitudes to religion in the secular 'West', in general (Chudinova 2020). The concept of God who punishes sinful humanity comes to the fore in all these cases, and acquires a geopolitical shade.

'Magical fundamentalism' absorbs elements of Russian geopolitical Messianism, and allies with the conspiratorial stream in Russian political Orthodoxy. The pandemic for them, as for many other COVID-dissidents across the globe, is nothing more but the media 'hype', initiated by some powerful and hidden financial centres for the purpose of consolidating their iron grip over humanity, and manipulating people's opinions and emotions (Timrot 2020; Prokhvatilov 2020). The narrative about COVID-19, as part of the information warfare (arguably targeting Russia), gained much traction in the fundamentalist milieu (Larina 2020). Aleksandr Shchipkov, for example, interpreted the quarantine measures as a gigantic experiment, initiated by the 'liberal fundamentalists' in the West, who wanted to implant fear in society, block critical thinking, and ultimately making Russia forget about its 'vocation' and civilization identity (Shchipkov 202ob). This secular version of the conspiratorial narrative in Orthodox believers' circles, is supplemented and reinforced by the idea that, the ultimate beneficiary of the 'corona-panic' is the devil. It becomes clear for the fundamentalistconspirators in this context that, closure of the churches for quarantine purposes is the part of the devil's plan to hinder people's way to salvation.

Ruskline.ru also explores the conspiratorial angle of the geopolitical interpretation of COVID-19. Valentin Katasonov, one of its publicists, for example, maintains that, the pandemic was initiated and orchestrated by the global anti-Christian plot, acting through such international organisations as WHO and IMF (Katasonov 2020). The reality of the virus and the pandemic is a variable: some accept it as an empirical fact, others do not - 
but the consensual opinion on ruskline.ru is that, the virus, real or otherwise, created a massive media-pandemic, which has its evil curators, hidden beneficiaries, and domestic agents (e.g. Romanov Igor' 2020a). One of the publicists of ruskline.ru penned, 'the more traitors, corrupt functionaries, and homosexuals there are in Russia, the greater the pandemic of COVID' (Romanov Igor' 2020b).

This section has related the Messianic, geopolitical, and conspiratorial thinking about COVID-19 with the broader ideological context of today's Russia. It has demonstrated that, the fundamentalist reaction to the pandemic had not come from the fringes of the public sphere, but instead, stemmed from the ideological mainstream of the last decade or so, which took its shape during President Putin's return to the Kremlin in 2012, and the so- called 'conservative turn' in Russian politics (Suslov\&Uzlaner 2019).

\section{Conclusion}

The period of the pandemic augmented the already present problems of the ROC, and made covert problems more visible and debatable. Observers point at the impending crisis, which is looming large behind the façade of the officially unassailable monolith of the Russian Orthodoxy. The contours of this crisis, which are becoming visible through the perspective of the pandemic, include the following components. First, the widening divisions between the centre-conservative part of the Church, and its reformist and fundamentalist flanks; on the one hand, the 'official ROC' is cutting itself off from the sources of renovation, and on the other, it is running the risk that, its social basis will shrink considerably. Second, the interrelationship between the religious fundamentalist camp and the secular regime ideology; in this light, the fundamentalist flock of the Church is nothing more than the amplified results of the state's efforts to nurture political passivity among the population, augmented by the ideologies of geopolitical exceptionalism and isolationism. Third, the Church's over-reliance on the state within the concept of the 'symphonia' of the secular and religious authorities. This questions the ability of the ROC to carry out a meaningful dialogue with society, and to take responsibility for advising on a religious way of actions in non-religious, everyday life. Finally, the continuation of 
the 'digital anxiety' among the ROC's clerics and lay people comes into obvious conflict with the increasing digitalisation of all social spheres as an instrument of mitigating the corona-crisis. The pandemic is the 'moment of truth' for the ROC, when it is able to meaningfully address the above-mentioned issues, and prove to be socially relevant to Russian society as a whole, lest it retreats into splendid isolation, and entertains the sectarian self-perception as an island of chastity in the sea of apostasy.

\section{References}

"Doverie politikam," 2020. Levada, 29 May, available at: https://www. levada.ru/2020/05/29/doverie-kpolitikam/

"Instruktsiia nastoiateliam..." 2020. Patriarchia.ru, 17 March, available at: http://www.patriarchia.ru/db/ text $/ 5608418 . \mathrm{html}$

"Na press-konferentsii." 2020. Patriarchia.ru, 3 March, available at: http://www.patriarchia.ru/db/ text/5601623.html.

"Otets Sergii prizval." 2020. 66.ru, 9 June, available at: https://66.ru/ news/society/231617/

"Velikii post i religioznost." 2020. Levada, 3 March, available at: https://www.levada. $\mathrm{ru} / 2020 / 03 / 03 / v e l i k i j-p o s t-i-$ religioznost/.

Adamsky, Dmitry. 2020. Russian Nuclear Orthodoxy. Stanford: Stanford University Press. Agadjanian, Alexander. 2017. "Tradition, Morality and Community: Elaborating Orthodox Identity in Putin's Russia." Religion, State \& Society 45(1): 39-60.

Alfeev, Metropolitan Hilarion. 2014. Tserkov' i mir: Dialogi o vremennom i vechnom. Moscow: Eksmo.

Alfeev, Metropolitan Hilarion. 2020a. "Esli epidemiia koronavirusa kosnetsia..." Patriarchia.ru, 10 March, available at: http://www.patriarchia.ru/db/ text/5604795.html;

Alfeev, Metropolitan Hilarion. 2020b. "Ne boish'sia zarazit'sia sam, podumai o drugikh." Patriarchia.ru, 24 March, available at: http://www. patriarchia.ru/db/text/5612210. html

Almond, Gabriel A., R. Scott Appleby, and Emmanuel Sivan. 2003. Strong Religion: The Rise of Fundamentalisms around the World. Chicago: University of Chicago Press.

Badmaev, arch-priest Nikita. 2020. "Propoved"' 14 April, available at: http://horduhovenstva.ru/ duxovenstvo/b/badmaev-nikita/ Basis of the Social Concept. 2000, available at: https://mospat.ru/en/ documents/social-concepts/iii/. Bogdanova, Ol'ga. 2020. "Pomozhet li kolokol'nyi zvon ot koronavirusa." Foma, 26 March, available at: https://foma.ru/ pomozhet-li-zvon-otkoronavirusa.html Bremer, Thomas. 2013. Cross and Kremlin: A Brief History of the Orthodox Church in Russia. Grand Rapids: W. B. Eerdmans Publishing.

Chapnin, Sergei. 2020a. "Razgovor o budushchem tserkvi." In Chapnin (ed.). Sistemnye problemy pravoslaviia: Analiz, 
osmyslenie, poiski reshenii.

Moscow: "Sobornost".

Chapnin, Sergei. 202ob.

"Pravoslavnyi fudamentalizm:

Privedet li pandemiia k raskolu

RPTs." Carnegie Moscow Center,

29 June, available at: https://

carnegie.ru/commentary/82167?fb

clid=IwAR 3 GBkvmKqsNSTygdP

A9jvno91U3a1MYezo2smGQlC-

z9TBH2hnrehq5SDlw

Chapnin, Sergei. 2020c. "Fenomen Sergiia: Kak monakh-raskol'nik stal avtoritetnee i populiarnee patriarkha Vseia Rusi.” 66.ru, 21 August, available at: https://66.ru/ news/society/233559/?fbclid=IwA R2pLmWaktwNTEsPzZWnUSh3 D2w61y67rUDWFkjis5509vWL4567Myb-k8I

Chudinova, Galina. 2020. "Kak pobedit' kovid." Ruskline.ru, 5 November, available at: https:// ruskline.ru/news_rl/2020/11/05/ kak_pobedit_kovid

Cimbalo, Giovanni. 2020. "Il papa e la sfida della pandemia." Stato, chiese e pluralismo confessionale 9.

Curanović, Alicja. 2019. "Russia’s Mission in the World: The Perspective of the Russian Orthodox Church." Problems of Post-Communism 66(4): 253-67.

Daniel, Wallace. 2006. The Orthodox Church and Civil Society in Russia. College Station: Texas, A\&M University Press. Dawisha, Karen. 2015. Putin's Kleptocracy: Who Owns Russia? New York: Simon and Schuster.

Dorofeev, Gennady. 2020. "Eta strannaia Paskhal'naia noch"' Ruskline.ru, 21 April, available at: https://ruskline.ru/news_ rl/2020/04/21/eta_strannaya_ pashalnaya_noch Druz', Igor'. 2020. "Besy i korona.” Ruskline.ru, 12 November, available at: https://ruskline.ru/ opp/2020/11/12/besy_i_korona
Duncan, Peter. 2002. Russian Messianism: Third Rome, Revolution, Communism and After. New York: Routledge.

Ely, Christopher. 2002. This Meager Nature: Landscape and National Identity in Imperial Russia. DeKalb: Northern Illinois UP. Faustova, Milena. 2020. "Sinod RPTs ustroil sumbur vmesto reform." Nezavisimaia gazeta, 2 September, available at: https:// www.ng.ru/ng religii/2020-09-01/9_493_reform. html.

Fedosov, Archpriest Andrei. 2020. "Koronavirus i RPTs." Kiberpop $T V, 30$ March, available at: https://www.youtube.com/ watch? $\mathrm{v}=1$ rivg FownVU

Flores, Fabián Claudio. 2020. "Espasialidad y religiosidad en tiempos de COVID-19: Apuntes preliminaries desde la geografía de las religiones." Espaço e cultura 47.

Gel'man, Vladimir. 2015. Authoritarian Russia: Analyzing Post-Soviet Regime Changes. Pittsburgh: University of Pittsburgh Press.

Guliamov, Archpriest Bogdan. 2020. “Tserkov' i tsifra." LB.ua, 16 June, available at: https://lb.ua/ blog/bogdan_guliamov/459911_ tserkov_tsifra_zametki.html

Gundiaev, Patriarch Kirill. 2009a. Patriarkh i molodezh': Razgovor bez diplomatii. Moscow:

Danilovskii blagovestnik.

Gundiaev, Patriarch Kirill. 20ogb. Sviataia Rus' - vmeste ili vroz'?

Patriarkh na Ukraine. Moscow:

Danilovskii blagovestnik.

Gundiaev, Patriarch Kirill. 2010. Byt'vernym Bogu: Kniga besed so Sviateishim Patriarkhom Kirillom. Minsk: Izd-vo Bel.ekzarkhata. Gundiaev, Patriarch Kirill. 2020. "Patriarshaia propoved'..."
Patriarchia.ru, 29 March, available at: http://www. patriarchia.ru/db/text/5613859. html

Halik, Tomas. 2020. "Christianity in the Time of Sickness." 3 April, available at: http://halik.cz/en/ tvorba/clanky-eseje/clanek/642/ Hovorun, Cyril. 2020a.

"COVID-19, Eucharist, Christian (?) Dualism and the Deadly Orthodox Fundamentalism." In P. Vassiliadis and G. Democopoulos (eds.) The Church in the Period of Pandemic: Can the Present

Pandemic Crisis Become a Meaningful Storm for Renewal in Our Churches? Fordham: CEMES: 159-164.

Hovorun, Cyril. 202ob. "On COVID-19 and Fundamentalism." 12 May, available at: https://www. youtube.com/ watch?v=RiSuXOF1qU4

Juergensmeyer, Mark. 2003. Terror in the Mind of God: The Global Rise of Religious Violence. Berkeley: University of California Press.

Katasonov, Valentin. 2020. "Dlia Vsemirnogo banka COVID-19 stanovitsia 'vechnoi' problemoi." Ruskline.ru, 16 November, available at: https://ruskline.ru/ news_rl/202o/11/16/dlya_ vsemirnogo_banka_stanovitsya_ vechnoi_problemoi

Knox, Zoe. 2004. Russian Society and the Orthodox Church: Religion in Russia after Communism. New York: Routledge.

Kolesnik, Father Maksim. 2020. "Interv'iu." Dvizhenie 'Sorok sorokov', 30 May, available at: https://vk.com/video53664310_456241228? list $=4 \mathrm{a} 42375$ $4 \mathrm{a} 238145 \mathrm{fib}$

Kots, Aleksandr, and A. Chelyshev. 2017. "Kto maliuet voinu s 
'Matil'doi' pod pravoslavie."

Komsomol'skaia Pravda, 15

September, available at: https:// www.kp.ru/daily/26731/3758899/)

Krasil'nikov, Mikhail. 2020. "Ia budu tselovat' sviatye moshchi." Ruskline.ru, 30 March, available at: https://ruskline.ru/ analitika/2020/03/3o/skazanie_o_ koronaviruse

Larina, Elena. 2020. "COVID-19 kak global'naia spetsoperatsiia." Ruskline.ru, 13 October, available at: https://ruskline.ru/ opp/2020/10/13/_kak_globalnaya_ specoperaciya

Laruelle, Marlene. 2012.

"Conspiracy and Alternate History in Russia: A Nationalist Equation for Success?" The Russian Review 71(4): 565-80.

Laruelle, Marlene. 2020. "Ideological Complementarity or Competition? The Kremlin, the Church, and the Monarchist Idea in Today's Russia." Slavic Review 79 (2): 345-64.

Latushko, Father Igor. 2020. "Otvechaiut batiushki." SviatoElisavetinskii monastery, 30 March, available at: https://www. youtube.com/ watch?v=pT 4 BA $97 \mathrm{Cmbo}$

Legoida, Vladimir. 2020a. "Iz-za pandemii ideal potrebitel'skogo obshchestva okonchatel'no razrushen." Ruskline.ru, 14 November, available at: https:// ruskline.ru/politnews/2020/11/14/ vr_legoida_izza_pandemii_ideal_ potrebitelskogo_obwestva_ okonchatelno_razrushen

Legoida, Vladimir. 202ob. "V situatsii s koronavirusom."

Patriarchia.ru, 16 March, available at: http://www.patriarchia.ru/db/ text/5608156.html

Lemeshonok, Father Andrei. 2020a. "Ugrozhaet li koronavirus Russkoi Pravoslavnoi Tserkvi?”
Sviato-Elisavetinskii monastery, 20 March, available at: https:// www.youtube.com/ watch? $\mathrm{v}=\mathrm{qX}$ osbxLrbcY

Lemeshonok, Father Andrei. 202ob. "Khochetsia prikladyvat'sia k sviatyniam." Sviato-Elisavetinskii monastery, 9 April, available at: https://www. youtube.com/ watch? $\mathrm{v}=9 \mathrm{uaRyuBrnPo}$

Levada, Iurii, 2001. "Homo PostSovieticus." Sociological Research 40(6): 6-41.

Lewis, David. 2020. Russia's New Authoritarianism: Putin and the Politics of Order. Edinburgh: EUP. Lipset, Seymour. 1996. American Exceptionalism: A Double-Edged Sword. New York: W.W. Norton.

Lorenzo, Miguel. 2020. "Cañizares dice que la vacuna del virus se busca mediante 'fetos abortados."' El Periódico, 10 September, available at: https://www. elperiodico.com/es/ sociedad/20200615/arzobispovalencia-vacuna-coronavirusobra-diablo-8000461

Luchenko, Ksenia. 2020. "Shiroko zakrytye dveri: Chto sluchilos's russkoi tserkov'iu vo vremia pandemii." Carnegie Moscow Center, available at: https:// carnegie.ru/commentary/81681?fb clid=IwARijvYFxs9mm3q1_ e1PXpRl6eiUooHvECNojpkNTUrcKtGygiYdjRiAXKeY. [accessed.

Luxmoore, Jonathan. 2020. "East European Catholics Draw Lockdown Parallels with Communist Rule." Catholic News Service, 14 April, available at: https://www.catholicnews.com/ east-european-catholics-drawlockdown-parallels-withcommunist-rule/

Marty, Martin E. and R. S. Appleby (eds.) 1995. Fundamentalism
Comprehended (The

Fundamentalism Project. Chicago: The University of Chicago Press. Matiushin, Father Roman. 2020. "Maloverie." Stikhi.ru, 22-23 March, available at: https://stihi. $\mathrm{ru} /$ diary/krasirina/2020-03-25 Mikhalkov, Nikita. 2020. "U kogo v karmane gosudarstvo." Besogon, 1 May, available at: https://www. youtube.com/ watch?v=MEtaaNNuVCI. Mitrofanova, Anastasia. 2005. The Politicization of Russian Orthodoxy: Actors and Ideas. Soviet and Post-Soviet Politics and Society. Stuttgart: Ibidem.

Molteni, Francesco, et al. 2020. "Searching for Comfort in Religion: Insecurity and Religious Behaviour during the COVID-19 Pandemic in Italy." European Societies, ahead-of-print, DOI: 10.1080/14616696.2020.1836383. Moser, Maria. 2020. "Ethische Konflikte in Zeiten von Corona." Argumentarium Nr. 7 des Instituts fur offentliche Theologie und Ethik der Diakonie (Wien), available at: https://diakonie.at/sites/default/ files/diakonie_oesterreich/ethik/ argumentarium_corona-200525. pdf

Nazarets, Evgeniia, L. Pal'veleva and T. Vol'tskaia. 2015. "Akt vandalizma 'Bozh'ei Voli.' Radio Svoboda, 15 August, available at: https://www.svoboda. org/a/27190622.html)

Nedelescu, Hermina. 2020. “The Eucharist, Its Physical Elements, and Molecular Biology." Public Orthodoxy, 27 May, available at: https://publicorthodoxy. org/2020/05/27/the-eucharist-itsphysical-elements-andmolecular-biology/?fbclid=IwAR oD2EmbjYfs9NqjiwlzFQvkfiIQBobhnNhPm

iNM4jT4UW9e2dkM_JF-Io 
Novopashin, bishop Aleksandr. 2020. "Koronavirusnoe 'bogoslovie"' Radonezh, 26 March, available at: https://radonezh. $\mathrm{ru} / 2020 / 03 / 26 /$ protoiereyaleksandr-novopashinkoronavirusnoe-bogoslovie Ortmann, Stefanie and John Heathershaw. 2012. "Conspiracy Theories in the Post-Soviet Space." Russian Review 71(4): 551-64.

Paura, Roberto. 2020. "L'ermeneutica delle epidemie nel pensiero Cristiano e l'idea del'Dio punitore." Orbis Idearum 8(1): 41-67.

Prokhvatilov, Vladimir. 2020.

"Mediavirus." Ruskline.ru, 20 October, available at: https:// ruskline.ru/opp/2020/10/20/ mediavirus_ili_skolko_zhiznei_ na_schetu_koronavirusnoi_ infodemii

Rediger, Patriarch Aleksii. 2007.

“Nel'zia bol'she zamykat'sia vnutri tserkovnoi ogrady." Pravoslavnaia gazeta, 8 April, available at: https://www.orthodoxnewspaper.ru/numbers/at47209

Richters, Katja. 2012. The PostSoviet Russian Orthodox Church: Politics, Culture and Greater Russia. New York: Routledge. Romanov, Father Sergii. 2020. "Sermon." 27 April, available at: https://www.youtube.com/ watch?v=CzxECha2nqY

Romanov, Igor'. 2020a. "My nash, my novyi ad postroim.” Ruskline. $r u, 16$ November, available at: https://ruskline.ru/news_ rl/2020/11/16/my_nash_my_ novyi_ad_postroim

Romanov, Igor'. 202ob. “A poshla by eta Amerika." Ruskline.ru, 5 November, available at: https:// ruskline.ru/news_ rl/2020/11/o5/a_poshla_by_eta_ amerika
Rybakov, Sergii. 2020. "Pandemii i voiny - neizbezhnye posledstviia bogoborchestva." Ruskline.ru, 17 November, available at:

Sena da Silveira, Emerson. 2020.

“'CATHOLICOVID-19” or QUO VADIS CATHOLICA ECCLESIA:

The Pandemic Seen in the Catholic Institutional Field." International Journal of Latin American Religions, ahead-of-theprint.

Sevriuk, Metropolitan Anatolii. 2020. "Dukhovenstvu dano ukazanie." Patriarchia.ru, 28 February, available at: http://www. patriarchia.ru/db/text/5599080. html

Shchipkov, Aleksandr. 2020 .

"Programma Aleksandr Shchipkov no. 136". TV Channel Spas, 17 May, available at: https:// www.youtube.com/ watch? $\mathrm{v}=$ BXEuaJaoMbc\&feature=emb_logo

Shchipkov, Aleksandr. 202ob.

"Obshchestvo strakha." 28

September, available at: https:// www.youtube.com/ watch? $\mathrm{v}=4 \mathrm{jzY}$ YszrGec

Shnirelman, Victor. 2012. "Russian Orthodox Culture or Russian Orthodox Teaching? Reflections on the Textbooks in Religious Education in Contemporary Russia." British Journal of Religious Education 34 (3): 263-79. Shnirelman, Victor. 2019. "The

Russian Orthodoxy and a Conspiracy Theory: A

Contemporary Discourse." Kirchliche Zeitgeschichte 32(1): 87-101.

Sil'chenkov, Father Igor'. 2020.

"Pochemu Bog popustil koronavirus liudiam?” 25 March, available at: https://www.youtube. com/watch?v=IukukAJzNls

Simons, Greg and David Westerlund. Eds. 2015. Religion,
Politics and Nation-Building in Post-Communist Countries.

Farnham: Ashgate Publishing Ltd. Skobiola, Bishop Amvrosii. 2020. "Uboialis' tam, gde net strakha." 17 March, available at: https:// www.youtube.com/ watch? $\mathrm{v}=\mathrm{oL} 8 \mathrm{tOWhlQ} 4 \mathrm{O}$ Soldatov, Aleksandr. 2020. "Milost' Bozhia' ili morovaia iazva?" Novaia gazeta, 26 March, available at: https://novayagazeta. ru/articles/2020/03/26/84523milost-bozhiya-morovaya-yazva Stoeckl, Kristina. 2016. “The Russian Orthodox Church as Moral Norm Entrepreneur." Religion, State \& Society 44 (2): 132-51.

Striet, Magnus. 2020. "Freiburger Fundamentaltheologe kritisiert Umgang des Papstes mit CoronaKrise.” Neue Ösnabrücker Zeitung, 8 April, available at: https://www. presseportal.de/ $\mathrm{pm} / 58964 / 4567002$

Suslov, Mikhail (ed.). 2016. Digital Orthodoxy in the Post-Soviet World: The Russian Orthodox Church and Web 2.o. Stuttgart: Ibidem.

Suslov, Mikhail and D. Uzlaner (eds.) 2019. Contemporary Russian Conservatism: Problems, Paradoxes and Perspectives. Leiden: Brill Suslov, Mikhail. 2014. "'Holy Rus': The Geopolitical Imagination in the Contemporary Russian Orthodox Church." Russian Politics \& Law 52(3): 67-86.

Suslov, Mikhail. 2016. “The Russian Orthodox Church in Search of the Cultural Canon."

Transcultural Studies 12 (1): 39-65. Suslov, Mikhail. 2020. Geopolitical Imagination: Ideology and Utopia in Post-Soviet Russia. Stuttgart: Ibidem.

Taylor, Brian. 2018. The Code of Putinism. Oxford: Oxford 
University Press.

Timrot, Bishop Amvrosii. 2020.

"Reaktsiia Pravoslavnoi Tserkvi na koronavirus." 16 November, available at: https://www.youtube. com/watch? $\mathrm{v}=\mathrm{YEM}>\mathrm{PlCBwDA}$

Uffelmann, Dirk. 2010. Der erniedrigte Christus: Metaphern und Metonymien in der russischen Kultur und Literatur. Köln:

Böhlau.
Velikanov, arch-priest Pavel. 2020. "Koronavirus i Tserkov':

Promezhutochnye itogi." 12 April, available at: https://bogoslov.ru/ article/6026984

Verkhovskii, Aleksandr. 2003. Politicheskoe pravoslavie: Russkie pravoslavnye natsionalisty $i$ fundamentalisty, 1995-2001. Moscow: Sova.

Vogt, Markus. 2020. “Resilience and Sustainability in the Corona Crisis." International Journal of Orthodox Theology 11(1).

Zygmont, Aleksei and B. Knorre. 2019. "Voiny, mstiteli, mucheniki: Agiologiia militantnogo diskursa $\mathrm{v}$ sovremennom rossiiskom pravoslavii." Studia Religiosa Rossica 2: 11-35. 